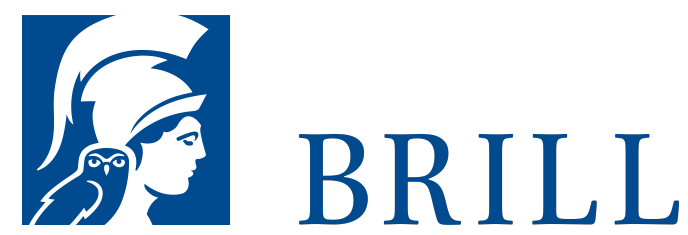

\title{
Offenbarung und Gewalt
}

Literarische Aspekte kultureller Krisen um 180o

Author: Bernd Hamacher

Die heute allgegenwärtige Debatte um das Gewaltpotenzial von (Offenbarungs-)Religionen beginnt mit der wechselseitigen metaphorischen Ersetzung von Offenbarung und Gewalt gegen Ende des 18. Jahrhunderts. Hamachers Buch rekonstruiert die literarische Vorgeschichte der bedeutendsten Krise der Moderne, die am 11. September 2001 ihren vorläufigen Höhepunkt erreichte. Offenbarung und Gewalt bilden eine Schnittmenge, die als Störung lebensweltlicher Normalität, als Einbruch in den Sinnzusammenhang der Kultur beschreibbar ist und in den Jahrzehnten um 1800 im Zuge kultureller Selbstreflexion in der Literatur verhandelt wird. Durch die Analyse der textuellen Krisenherde - mit Hauptkapiteln zu Lessing, Kleist und Goethe - lässt sich ein literaturwissenschaftlicher und -geschichtlicher Beitrag zu aktuellen kulturkritischen Debatten formulieren

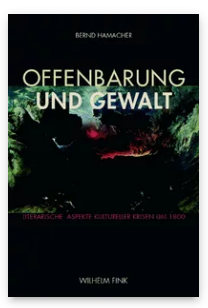

Pages: 437

Seiten

Language:

German

Subjects:

General,

Literature and

Cultural Studies

Publisher: Brill |

Fink

E-Book (PDF)

Released online: 24 Sep 2019

ISBN: $978-3^{-}$

8467-4895-4

List price

USD $\$ 42.00$

Paperback

Publication date:

og Dec 2009

ISBN: 978-3-

7705-4895-8

List price

USD \$42.00 
For more information see brill.com

Order information: Order online at brill.com +44330 333 0049 | customerservices@brill.com Submission information: brill.com/authors

Titles published by Brill | Fink, Brill | mentis or Brill | Schöningh: +49(o)715413279216| brill@brocom.de 